\title{
THE RELATIONSHIP BETWEEN SEMEN CHARACTE- RISTICS AND COLOUR DOPPLER ULTRA- SOUND MEASURES OF TESTICULAR BLOOD FLOW IN BUCKS
}

\author{
I.I. El-Kon \\ Theriogenology Dept., Fac. Vet. Med., Tanta University (Kafr El-Sheikh Branch)
}

\section{ABSTRACT}

The present study was carried out to evaluate the potential use of colour Doppler ultrasound to measure blood flow to the buck testis and to establish reference values for Doppler measures of blood flow in the testicular artery of the buck. Testes from both young and adult bucks were examined using a pulsed wave colour Doppler ultrasound with a linear array(5 MHz)transducer.Resistance index (RI), pulsatility index (PI) and systolic diastolic ratio $(S / D)$ of the testicular artery were measured at the level of spermatic cord.Semen samples were collected from the two groups of buck once weekly. Semen characteristics were compared in the two groups, as well as the correlations between semen characteristics, age and blood flow measures were determined. Blood flow measures were similar for left and right testes. Resistance index was significantly lower $(P<0.05)$ in young than in adult bucks. Highly significant $(P<0.01)$ correlations were recorded between semen char-acteristics and blood flow measures (RI, PI and S/D) in bucks.

Keywords: Bucks, age, testis, colour Doppler ultrasound, semen characteristics.

\section{INTRODUCTION}

Ultrasonography has rapidly become established as one of the principle imaging techniques used in veterinary practice.It allows the clinician to obtained instant information about a wide range of body systems and in some cases the dynamic function of the organs can be assessed. In addition, ultrasonography has led to new insights into basic anatomy and physiological processes (Goddard, 1995).Colour Doppler ultrasound has 
become a method of choice to evaluate vasculature of various organs, including testes. In human medicine, this technique has been employed to evaluate blood flow in the testicular artery and has been applied in diagnosing testicular pathology associated with altered blood flow, such as torsion of spermatic cord, testicular infarction or varicocele (Aydos et al., 1993; Sidhu, 1999;Pavlica and Barozzi, 2001). In recent years, Doppler ultrasonography has greatly become available for use in veterinary practice. The use of Doppler ultrasonography to characterize blood flow was also recorded in stallion (Pozor and McDonnel, 2002) and dog (Hricak et al., 1983). The relationship between blood flow and sperm production was recorded (Biagiotti et al., 2002) whereas, Resistance index (RI) as well as peak systolic velocity(PSV)values are reliable indicators for sperm production, since these parameters were highly correlated with sperm production rate score (Biagiotti et al., 2002).

The ultrasonographic appearance of the normal testes and epididymides of goat was described (Agumbah et al., 1995;Ahmad et al.,1991) as well as the abnormal tests (Ahmad et al., 1993; Eilts et al., 1989). Despite the fact that ultrasound has been extensively used to evaluate vasculature of human testes, little information are available on the use of Doppler ultrasonography in male goat.

Therefore, the objectives of the present study were to (1) determine the feasibility of colour Doppler ultrasound for evaluating the vasculature of the buck testis and (2) determine the relationships amongst blood flow measures (RI, PI and S/D), age and semen characteristics in male goat.

\section{MATERIALS AND METHODS}

\section{1- Animals:}

Eight healthy male goats kept under the standard management conditions were used in the present study. The animals were assigned on the basis of age into two experimental groups, young and adult each of 4 bucks. The bucks in the young group (G1) were 12-18 months old and 
had a body weight ranging from $20-25 \mathrm{~kg}$ while those in adult group (GII) were 24-30 months old and had a body weight ranging from $30-35 \mathrm{~kg}$.

\section{2- Ultrasound examination:}

The animals were restrained in dorsal recumbancy. For each buck, each of the two testes was weekly evaluated using a pulsed-wave colour Doppler ultrasound with a linear-array transducer $5 \mathrm{MHz}$ (Acuson-128x) connected to a vediographic printer (up, sony). Resistance index (RI), pulsatility index (PI) and systolic dystolic ratio (S/D) were measured every week.

\section{3- Semen collection and evaluation:}

Semen samples were collected using electroejaculator once weekly from each buck over a period of 12 weeks. One ejaculate was collected on each day of collection. Immediately after collection the samples were evaluated for volume, mass motility, individual motility according to Salisbury et al. (1978). The percentages of live sperms as well as morphologically abnormal spermatozoa were determined by Eosin-Nigrosin staining technique according to Campbell et al. (1956). The sperm cell concentration was determined by using Neubauer haemocytometer.Semen samples were collected at the same day of ultrasound examination.

\section{4- Statistical analysis:}

The obtained data were analyzed using a computerized statistical analysis system (SAS, 1990) and expressed as mean \pm SEM. Mean values of blood flow (pulsatility index (PI) Resistance index (RI) and systolic diastolic ratio (S/D) for right and left testes were compared using student"t"test. Similarly,values for young and adult groups were compared using " $t$ " test. The relationships amongst the studied parameters were estimated by correlation coefficients. All statistical methods were carried out according to Snedecor and Cochran (1980).

\section{RESULTS}

Colour Doppler ultrasound image of the convoluted aspect of the testicular artery in the spermatic cord was easily visualized. 
The wave forms of blood flow to the buck testes were mostly resistive biphasic wave forms at the level of spermatic cord (Fig. 1).

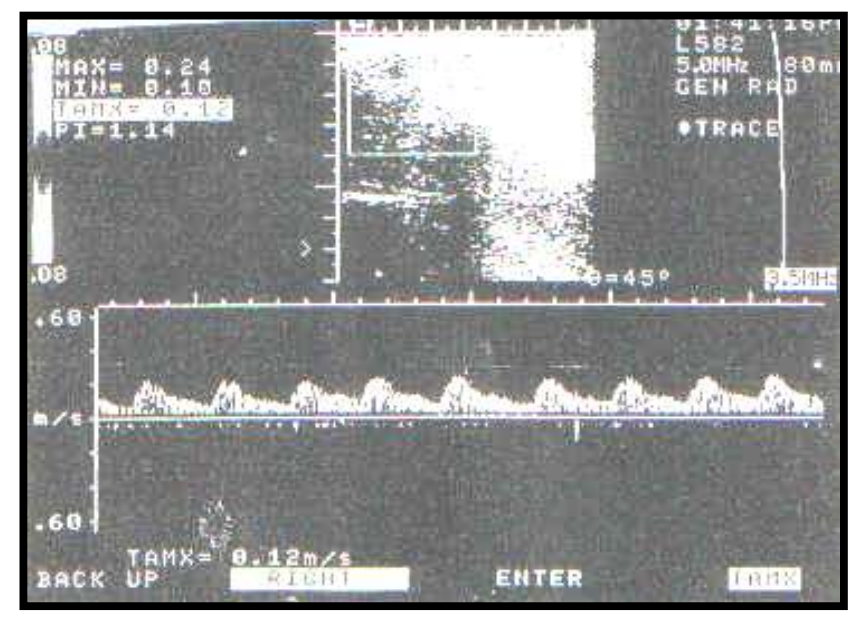

Fig. (1): Wave forms of blood flow to the buck testes.

As shown in Table 1,there was a non significant difference $(\mathrm{P}>0.05)$ between blood flow measures (PI, RI and S/D) of the right and left testes in both young (GI) and adult (GII) bucks.

Table (1): Means+ SEM for blood flow measures (PI, RI and S/D) of right and left testicular arteries of bucks.

\begin{tabular}{|c|c|c|c|c|}
\hline \multirow{3}{*}{ Measures } & \multicolumn{4}{|c|}{ Groups } \\
\hline & \multicolumn{2}{|c|}{ Group I $(n=48)$} & \multicolumn{2}{|c|}{ Group II $(n=48)$} \\
\hline & Right & Left & Right & Left \\
\hline $\begin{array}{l}\text { Pulsatility } \\
\text { Index (PI) }\end{array}$ & $\begin{array}{r}1.52 \mathrm{~A} \\
\pm 0.05\end{array}$ & $\begin{array}{l}1.48 \mathrm{~A} \\
\pm 0.05\end{array}$ & $\begin{array}{l}1.53 \mathrm{~A} \\
\pm 0.04\end{array}$ & $\begin{array}{l}1.41 \mathrm{~A} \\
\pm 0.05\end{array}$ \\
\hline $\begin{array}{l}\text { Resistance } \\
\text { index (RI) }\end{array}$ & $\begin{array}{r}0.71 \mathrm{~A} \\
+0.02 \\
\end{array}$ & $\begin{array}{r}0.69 \mathrm{~A} \\
+0.02 \\
\end{array}$ & $\begin{array}{l}0.85 \mathrm{~A} \\
+0.02 \\
\end{array}$ & $\begin{array}{l}0.80 \mathrm{~A} \\
+0.02 \\
\end{array}$ \\
\hline $\begin{array}{l}\text { Systolic diastolic } \\
\text { ratio (S/D) }\end{array}$ & $\begin{array}{l}3.39 \mathrm{~A} \\
\pm 0.12\end{array}$ & $\begin{array}{l}3.15 \mathrm{~A} \\
\pm 0.11\end{array}$ & $\begin{array}{l}3.29 \mathrm{~A} \\
\pm 0.11\end{array}$ & $\begin{array}{l}3.19 \mathrm{~A} \\
\pm 0.12\end{array}$ \\
\hline
\end{tabular}

Means in the same row carrying the same letters are not significantly different $(\mathrm{P}<0.05)$.

Among the various blood flow measures differences between age groups were not significant except RI was significantly $(\mathrm{P}<0.05)$ lower for young age (GI) than for adult (GII) age group (Table, 2). 
Table (2): Means + SEM for blood flow measures (PI, RI and S/D)of testicular arteries in young (GI) and adult (GII) bucks.

\begin{tabular}{||l||c|c|}
\hline \multicolumn{1}{|c||}{ Measures } & \multicolumn{2}{c|}{ Groups (n= 96) } \\
\cline { 2 - 3 } & Group I & Group II \\
\hline \hline Pulsatility & $1.50 \mathrm{~A}$ & $1.47 \mathrm{~A}$ \\
Index (PI) & \pm 0.03 & \pm 0.04 \\
\hline Resistance & $0.70 \mathrm{~B}$ & $0.82 \mathrm{~A}$ \\
index (RI) & \pm 0.01 & \pm 0.01 \\
\hline \multirow{2}{*}{ Systolic diastolic (S/D) } & $3.27 \mathrm{~A}$ & $3.34 \mathrm{~A}$ \\
& \pm 0.08 & \pm 0.09 \\
\hline
\end{tabular}

Means in the same row carrying the same letters are not significantly different $(\mathrm{P}<0.05)$

Table (3) show significant increase $(\mathrm{P}<0.01)$ in the sperm cell concentration, individual motility, mass motility, alive percent and semen volume in the adult than in young bucks. In addition Significant $(\mathrm{P}<0.01)$ decrease in the sperm cell abnormalities was recorded in adult than in young bucks.

The correlation between semen characteristics and the measures of blood flow (PI, RI, S/D) were summarized in Table, 4. Highly significant positive correlation $(\mathrm{P}<0.01)$ was recorded between pulsatility index $(\mathrm{PI})$ and sperm cell concentration. Whereas a significant negative correlation $(\mathrm{P}<0.01)$ was recorded between sperm cell abnormalities and pulsatility index while a significant positive corelation with individual motility percentage was noticed. On the other hand, there were non significant correlations between pulsatility index and each of ejaculate volume, mass motility and alive sperm percentage(Table, 4). On contrast, highly signifycant positive correlation $(\mathrm{P}<0.01)$ was recorded between resistance index and ejaculate volume. Highly significant positive correlations $(\mathrm{P}<0.01)$ were recorded between sperm cell concentration and each of pulsatility index, resistance index and systolic dystolic ratio. Significant negative Kafr El-Sheikh Vet. Med. J. Vol. 2 No. 2 (2004) 
correlations $(\mathrm{P}<0.01)$ were recorded between sperm cell abnormalities and each of pulsatility index, resistance index and systolic/dystolic ratio, whereas non significant positive correlations were recorded between a live sperm percentage and blood flow measures (PI, RI and S/D).

Concerning the correlation between semen characteristics, highly significant correlations were recorded between sperm cell concentration and each of mass motility score, individual motility percentage and alive sperm percentage. Highly significant negative correlations $(\mathrm{P}<0.01)$ were recorded between sperm cell abnormalities and each of mass motility score, individual motility percentage, alive sperm cells percentage and sperm cell concentration (Table, 4). However non significant positive correlations were recorded between ejaculate volume and each of sperm cell concentration, individual motility and mass motility.

Table (3): Means (+ SEM) of semen characteristics (ejaculate volume, mass motility, alive sperm percentage,sperm cell concentration and sperm cell abnormalities in young and adult bucks.

\begin{tabular}{|c|c|c|}
\hline \multirow{2}{*}{$\begin{array}{c}\text { Semen } \\
\text { characteristics }\end{array}$} & \multicolumn{2}{|c|}{ Groups $(n=96)$} \\
\hline & Group I & Group II \\
\hline Ejaculate volume (ml) & $\begin{array}{r}1.20 \mathrm{~b} \\
+0.04\end{array}$ & $\begin{array}{r}1.45 \mathrm{a} \\
+0.03\end{array}$ \\
\hline Mass motility (score) & $\begin{array}{r}3.50 \mathrm{~b} \\
\pm 0.08\end{array}$ & $\begin{array}{r}4.10 \mathrm{a} \\
\pm 0.09\end{array}$ \\
\hline Individual motility (\%) & $\begin{array}{l}75.94 b \\
\pm 0.84\end{array}$ & $\begin{array}{l}81.04 \mathrm{a} \\
\pm 0.93\end{array}$ \\
\hline Alive sperm (\%) & $\begin{array}{l}85.39 b \\
\pm 0.73 \\
\end{array}$ & $\begin{array}{l}89.27 \mathrm{a} \\
\pm 0.88\end{array}$ \\
\hline $\begin{array}{l}\text { Sperm cell concentration } \\
\left(\mathrm{x} 10^{9} / \mathrm{ml}\right)\end{array}$ & $\begin{array}{l}1.43 \mathrm{~b} \\
+0.07 \\
\end{array}$ & $\begin{array}{r}2.21 \mathrm{a} \\
+0.07 \\
\end{array}$ \\
\hline Sperm cell abnormalities (\%) & $\begin{array}{r}9.67 \mathrm{a} \\
\pm 0.46\end{array}$ & $\begin{array}{r}6.04 \mathrm{~b} \\
\pm 0.41\end{array}$ \\
\hline
\end{tabular}

Means in the same row carrying the same letters are not significantly different $(\mathrm{P}<0.05)$. 


\section{DISCUSSION}

Although colour Doppler ultrasound was used to evaluate blood flow to the testes of stallion, canine and human with some literature concerning these studies, there is no available literature concerning using of colour Doppler ultrasound for evaluation of blood flow to buck testes.

Colour Doppler ultrasound appeared to be more reliable in visualizing the lumen of testicular artery than gray-scale ultrasound. Colour Doppler seemed to improve the accuracy of the measurements of blood flow velocities and calculation of indices in the stallion due to the tortuous route of the testicular artery in the spermatic cord (Pozor and McDonnell, 2003). In the present study the wave forms of blood flow to the buck testes were mostly resistive biphasic wave forms at the level of spermatic cord.These findings coincided with the findings of Pozor and McDonnel(2003) who obtained that the wave forms of blood flow to stallion testes were mostly resistive, biphasic wave forms at the level of spermatic cord and nonresistive monophasic wave forms from the marginal aspect of testicular artery. On contrary, the wave forms of blood flow to human and canine testes appear to have non-resistive and monophasic wave forms(Middleton et al.,1989;Gunzel et al.,2001;Gumbsch et al.,2002). Resistive character of the wave forms from the convoluted part of buck testicular artery may be due to the relatively short spermatic cord with highly convoluted artery.

Of the three measurements that were obtained in the present study, RI and PI seemed to be more sensitive indicators of arterial blood flow than $\mathrm{S} / \mathrm{D}$, since they provided information on vascular impedance, not only velocity. Furthermore, the RI of the testicular artery seemed to be the most useful clinical measure of blood flow to and within the testis and epididymis (Pozor and McDonnell, 2003). It is usually altered by inflammatory process(Rifkin et al.,1987)and aging(Wielgos et al.,1998). As has been proved by the results of the present study the comparison between right and left testicular arteries in blood flow (PI, RI and S/D) measures revealed non significant $(\mathrm{P}<0.05)$ differences between right 
and lift testes (1.52 vs. $1.48,1.53$ vs. $1.41 ; 0.71$ vs. $0.69,0.70$ vs. 0.71 ; 3.39 vs. 3.15 and 3.29 vs. 3.19 ) for pulsatility index, resistance index and systolic/dystolic ratio in right and left testicular arteries in both young (GI) and adult (GII) bucks, respectively. These results coincided with the results of Pozor and McDonnell(2003)in stallion who reported that blood flow measures for right and left testicular artery were similar. There were non significant $(\mathrm{P}<0.05)$ differences between the young $(\mathrm{GI})$ and adult (GII) bucks in pulsatility index and systolic diastolic ratio and significant difference $(\mathrm{P}<0.05)$ in $\mathrm{RI}$ which was lower in young (GI) than adult (GII) bucks (0.70 vs. 0.82). Pozor and MacDonnel (2003) reported that, the differences between age groups were not significant for peak systolic whereas RI was significantly lower for the 11-15 year age than for the 16-22 years age group of stallion. Paltiel et al. (1994) and Wielgo et al. (1998) reported that RI values were lower in prepubertal than pubertal boys and were increased in aging men. In addition Patiel et al. (1994) suggested that larger volume of tests are associated with lower resistance index.

As reported by the present study the comparison between young and adult bucks in relation to semen characteristics revealed a positive correlation between age and semen characteristics (El-Wishy and El-Sawaf, 1974).

Concerning the correlation between the measures of blood flow (PI, RI,S/D)and semen characteristics of bucks, the results of the present study revealed highly significant positive correlation between pulsatility index (PI) and each of sperm cell concentration and individual motility and non significant positive correlations between PI and each of ejaculate volume, mass motility and a live sperm percentage. Resistance index(RI)was significantly correlated with ejaculate volume and sperm cell concentration. Significant negative correlations were recorded between sperm cell abnormalities and each of PI,RI and S/D ratio.However, such results may come in accordance with Biogiotti et al.(2002) who suggested that RI and peak $\overline{\mathrm{Kafr}}$ El-Sheikh Vet. Med. J. Vol. 2 No. 2 (2004) 
systolic velocity(PSV)were reliable indicators for sperm production, since these parameters were highly correlated with sperm production rate score in human.

Significant relationships were reported between sperm cell concentration and each of mass motility, individual motility, a live sperm percentage and total sperm cell abnormalities. These results were in partial agreement with that reported by Saxena and Tripathi(1980) in Jamunpari bucks. In the present study significant negative correlation was reported between individual motility and total sperm cell abnormalities. These results were come in accordance with that reported by Kaya et al. (1999) in Konyamerino rams.Highly significant correlation was recorded between individual motility and mass motility of spermatozoa, as the former parameters is the building unit for the latter one. However, non significant correlations were recorded between ejaculate volume and any of semen characteristics.

\section{It could e concluded that:}

1. Colour Doppler ultrasonographic of blood flow of the buck testis is possible and will become a useful tool for objective evaluation of the buck testis.

2. There was no significant differences between left and right testes in blood flow measures (PI, RI, S/D)

3. Age has a significant effect on some of the studied blood flow parameters.

4. Highly significant correlation was recorded between semen characteristics and blood flow measures (PI, RI, S/D) in bucks.

\section{REFERENCES}

- Agumbah,G.J.O.; Tafirei, G.; Mudense,D.and Shumba,W. (1995): Testicular ultrasonography in bucks and rams.Ind.Vet. J.,72: 829-834.

- Ahmad, N.; Noakes, D..E. and Subandrio, A.L.(1991): B-mode real time ultrasonographic imaging of the testis and epididymis of sheep and goat. Vet. Rec., 128(21): 491-496. 
- Ahmad, N.; Noakes, D.E. and Middleton, D.J. (1993): Use of ultrasound to diagnose testicular degeneration in a goat. Vet. Rec., 132: 436-439.

- Aydos, K.; Baltaci, S.; Salih, M.; Anafarta, K.; Beduck, Y. and Gulsoy, $\boldsymbol{U}$. (1993): Use of color Doppler sonography in the evaluation of varicoceles. Eur. Urol., 24: 221-225.

- Biagiotti,G.;Cavallini,,G.; Modenini,G.;Vitali,G.and Gianoroli, L. (2002): Spermatogenesis and spectral echo-colour Doppler traces from the main testicular artery BJU Int., 90: 903-908.

- Campbell, R.C.; Dott, H.M.and Glover,T.D.(1956): Nigrosin-Eosin as stain for differentiating live and dead spermatozoa. J. Agric. Sci., 48 (1): $1-8$.

- Eilts, B.E.; Pechman, R.D.; Tylor, H.W. and Usenik, E.A. (1989): Ultrasonographic evaluation of induced testicular lesions in male goats. Amer. J. Vet. Res., 50(8): 1361-1364.

- Goddard,P.J.(1995):In veterinary ultrasonography.First edition,pp. 1.

- Gumbsch, P.; Gabler, C. and Holzmana (2002): A colour-coded duplex sonography of the testes of dogs. Vet. Rec., 151: 140-144.

- Gunzel,A.R.;Mohrke, C. and Poulsen, C. (2001): Colour-coded and pulsed Doppler sonography of the canine testis,epididymis and prostate gland: physiological and pathological findings.Reprod.Dom.Anim.,36: 236-240.

- Hricak, H.; Lue, T.; Filly, R.A.; Alpers, C.E.; Zeinech, S.J. and Tanagho, E.A. (1983): Experimental study of the sonographic diagnosis of testicular torsion.J.of Ultrasound in Medicine, 2: 349-356.

- Kaya, A.; Yildiz, C.; Lehimcioglu, N.C.; Ergin, A. and Aksoy, M. (1999): Seasonal variation in sperm quality, testicular size and plasma testosterone concentrations in Konya Merino rams. Hayvancilik Arastirma Dergisis, 9: 1-5 (A.B.A. Vol. 68, No. 6819). 
- Middleton, W.D.; Thorne, D.A. and Nelson, G.L. (1989): Color Doppler ultrasound of the normal testis. Am. J. Radiol., 152: 293-297.

- Paltiel, H.J.; Rupich, R.C. and Babcock, D. (1994): Maturational changes in arterial impedance of the normal testis in boys; Doppler sonographic study: 163: 1189-1193.

- Pavlica,P. and Barozzi, L. (2001). Imaging of the acute scrotum. Eur Radiol., 11: 220-228.

- Pozor, M.A. and McDonnell, S.M. (2002): Doppler ultrasound measures of testicular blood flow in stallions. Theriogenology, 58: 437-440.

- Pozor, M.A. and McDonnell, S.M. (2003): Color Doppler ultrasound evaluation of testicular blood flow in stallions. Theriogenology, 61, 522-535.

- Rifkin,M.D.;Needleman,L.; Pasta, M.; Kurtz, A.B.; Foy, P.M. and McGlynn,E.(1987): Evaluation of renal transplant rejection by duplex Doppler examination: value of the resistive index. A.J.R., 148: 759.

- Salisbury,G.W.; Vandemark, N.L.and Lodge,J.R.(1978): Physiology of reproduction and artificial insemination of cattle. 2 ed.W.H.Freeman and Co. San, Francisco, USA.

- SAS (1990): Statistical analysis system. Users Guide Statistics, SAS Institute, Inc., Cary, N.C., USA.

- Saxena,V.B.and Tripathi, S.S.(1980): Note on physico-chemical and morphological attributes of semen of Jamnapari bucks. Ind. J. Anim. Sci., 50(9): 775-777.

- Sidhu, P.S. (1999): Clinical and imaging features of testicular torsion: role of ultrasound. Clin. Radiol., 54: 343-352.

- Snedecor, G.W. and Cochran, W.G. (1980). Statistical methods. $7^{\text {th }}$ ed. Ames, Iowa: Iowa State University Press.

- Wielgos, M.; Bablok, L.; Fracki, S. and Marianowski, L. (1998): Doppler flow measurements in testicular artery in scrotal inflammatory disease. Act Radiol., 38: 1026-1030. 
در اسـة العلاقة بين خصائص السائل المنوى وقياسات سريان الام للخصيه بجهاز الموجات المنوت

فوق الصوتية (الدوبلر) الملون فى ذكور الماعز

د.إسماعيل إسماعيل القن

قسم التوليد والتناسل والتلقيح الاصطناعي بكلية الطب البيطرى جامعة طنطا - فرع كفر الثيخ والثناعية

أجريت هذه الدراسة لتقييم استخدام جهاز الموجات فوق الصوتية (الدوبلر) الملون فى قياس معدل سريان الدم لخصية ذكور الماعز.

تم قياس معدل سريان الدم لكل من الخصيتين فى عدد ثمانية ذكور ماعز قسمت إلى مانى مجموعنين كل منهما تتنتمل على أربعة تيوس الأولى تثراوح من 12-18 شهر في العمر والثانية تتراوح

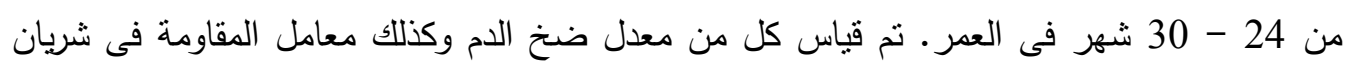

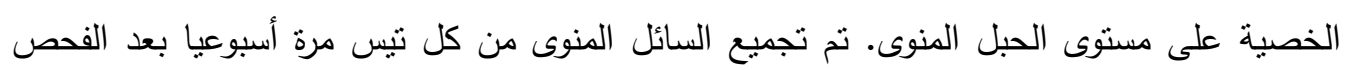

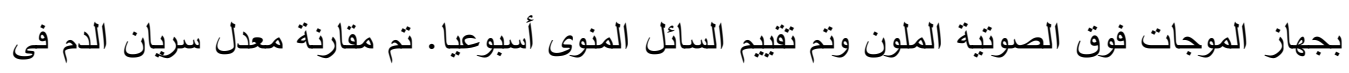

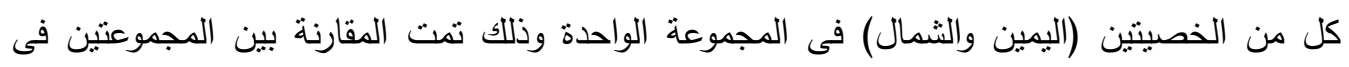
معدلات سريان الدم. تم مقارنة خصائص السائل المنوى فى المجموعنين ، كذلك تمت دراسة العلاقة بين خصائص السائل المنوى وقياسات سريان الدم فى ذكور الماعز • سجلت هذه الدراسة أنه لا يوجد فرق فى قياسات سريان الدم بين الخصيتين (اليمين والثمال) داخل المجموعة. وكذلك بين العمرين إلا فى معامل المقاومة وجد أنه أقل فى المجموعة الصغيرة. وجد أن هنالك

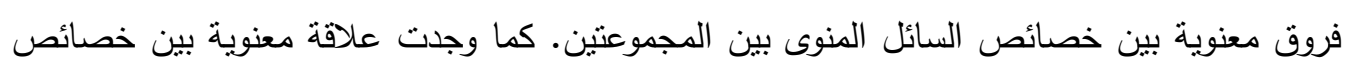
السائل المنوى وقياسات سريان الدم باستخدام جهاز الموجات فوق الصوتية الملون. 
استتتج من هذه الدراسة أن قياسات سريان الدم لها نأثثر وعلاقة قوية على خصائص السائل

المنوى. وأنه يمكن استخدام جهاز الموجات فوق الصوتية لتقييم قياسات سريان الدم للخصية. 